\title{
PENGEMBANGAN MEDIA PEMBELAJARAN INTERAKTIF BERBASIS LECTORA INSPIRE PADA MATERI LAPORAN HARGA POKOK
}

\author{
Nurvia Dwi Rahmawati ${ }^{1}$, Joni Susilowibowo ${ }^{2}$ \\ ${ }^{1}$ Universitas Negeri Surabaya, ${ }^{2}$ Universitas Negeri Surabaya \\ ${ }^{1}$ nurviarahmawati16080304052@mhs.unesa.ac.id, ${ }^{2}$ jonisusilowibowo@unesa.ac.id
}

\begin{abstract}
Abstrak: Penelitian pengembangan ini mempunyai tujuan untuk menghasilkan produk, menganalisis kelayakan serta respon peserta didik terhadap media pembelajaran interaktif berbasis lectora inspire pada materi laporan harga pokok di SMK Negeri 2 Tuban. Jenis penelitian ini ialah penelitian pengembangan dengan menggunakan model pengembangan ADDIE yang dimodifikasi oleh Branch. Penelitian ini menggunakan data kualitatif dan kuantitatif dengan instrumen pengumpulan data berupa angket terbuka dan angket tertutup. Teknis analisis data yang digunakan berupa analisis deskriptif yang berkaitan dengan aspek efektivitas melalui angket. Media pembelajaran interaktif ini divalidasi oleh dua ahli materi dan satu ahli media, serta diiujicobakan kepada 20 peserta didik kelas XII Akuntansi SMK Negeri 2 Tuban. Hasil akhir validasi ahli materi sejumlah 89,13\% dengan kategori "sangat layak", validasi ahli media sejumlah $84,89 \%$ dengan kategori "sangat layak", serta mendapat skor dari respon peserta didik sejumlah 94,22\% dengan kategori "sangat memahami". Sehingga dapat dinyatakan jika media pembelajaran ini sangat layak dipergunakan pada proses pembelajaran.
\end{abstract}

Kata Kunci: media pembelajaran interaktif, lectora inspire, laporan harga pokok

\begin{abstract}
This development research has the purpose to produce products, analyze the feasibility and response of students to interactive learning media based on Lectora inspire on the subject matter cost price report at SMK Negeri 2 Tuban. This type of research is development research using the ADDIE development model modified by Branch. This study uses qualitative and quantitative data with data collection instruments in the form of open questionnaires and closed questionnaires. Technical analysis of the data used in the form of descriptive analysis related to the aspect of effectiveness through the questionnaire. This interactive learning media was validated by two material experts and one media expert, and was trialled to 20 students of class XII Accounting of SMK Negeri 2 Tuban. The final result of material expert validation was 89,13\% with the category "very worthy", the validation of media experts was $84.89 \%$ with the category "very worthy", and received a score of $94.22 \%$ in the responses of students in the "very understanding" category. So, it can be stated if the interactive learning media is very decent when used in the learning process.
\end{abstract}

Keywords: interactive learning media, lectora inspire, cost price report

\section{PENDAHULUAN}

Pada zaman globalisasi saat ini, kemajuan teknologi dan informasi merupakan sesuatu yang lazim terjadi di masyarakat. Kemajuan teknologi dan informasi berdampak terhadap segenap dimensi kehidupan baik di bidang politik, ekonomi, sosial, budaya, terlebih di lingkungan pendidikan. Kemajuan teknologi dan informasi dalam lingkungan pendidikan sangatlah pesat. Hal ini disebabkan adanya revolusi industri 4.0. Revolusi industry 4.0 merupakan kelanjutan dari revolusi 3.0 yang terjadi sebelumnya. Pendidikan menjadi tonggak dalam peningkatan martabat manusia di Indonesia sehingga pendidikan di Indonesia perlu menyertai perkembangan zaman supaya sanggup bersaing dengan bangsa yang lain (Fatkhurrohman \& Susilowibowo, 2019). Pendidikan dituntut untuk selalu menyelaraskan dengan perkembangan teknologi dan informasi, terutama dalam hal peningkatan kualitas pendidikan.

Kualitas pendidikan di masa kini akan mencerminkan bagaimana peradaban bangsa di masa mendatang. Sehingga pendidikan yang berjalan sekarang ini bertujuan untuk menciptakan manusia yang seutuhnya. Usaha yang bisa dilaksanakan oleh pemerintah untuk memperbaiki kualitas pendidikan adalah dengan cara menyelenggarakan perubahan kurikulum. Pemerintah Indonesia sudah menyelenggarakan perubahan kurikulum dari masa ke masa. Kurikulum yang berlangsung pada masa kini yaitu kurikulum 2013. Dalam kurikulum 2013, kegiatan pembelajaran pada seluruh mata pelajaran menggunakan pendekatan saintifik. Pendekatan ini memiliki tujuan untuk membantu siswa dalam memecahkan suatu 
persoalan dengan menggunakan proses ilmiah melalui observasi, perumusan masalah, penghimpunan informasi dan pembuatan simpulan (Abidin, 2014:125). Guru harus dapat menjalankan pembelajaran sesuai dengan tuntutan kurikulum 2013 agar pembelajaran tersebut bisa lebih aktif dan efektif. Dengan adanya hal tersebut, guru harus bisa berinovasi untuk menciptakan pembelajaran yang selaras dengan ketentuan kurikulum 2013.

Pada kurikulum 2013, peserta didik didorong agar dapat aktif pada saat pembelajaran. Peserta didik diminta untuk menciptakan persepsi sendiri dalam kegiatan pembelajaran. Selain itu, peserta didik disediakan wadah untuk belajar berdasarkan ketertarikan, gaya belajar, serta kompetensi personalnya. Masing-masing peserta didik mempunyai perbedaan cara dalam belajar. Sebagian peserta didik bisa belajar dengan mendengar, melihat, membaca, dan menonton video tanpa bantuan orang lain. Dan sebagian lainnya membutuhkan interaksi dengan guru, teman, lingkungan sekolah, ataupun dengan dukungan orang lain. Selain itu, antara peserta didik satu dengan yang lainnya mempunyai gaya belajar yang tidak sama. Gaya belajar dianggap mempunyai kedudukan yang strategis dalam kegiatan pembelajaran. Gaya belajar merupakan kiat individu untuk memahami, menyerap, atau menangkap informasi.. Terdapat tiga bentuk gaya belajar, yaitu: gaya belajar visual, gaya belajar auditorial, dan gaya belajar kinestetik (Hamzah dalam Wahyuni, 2017). Masing-masing individu memiliki kecakapan yang berbeda dalam mengolah suatu informasi. Oleh karena itu, guru dapat menciptakan ruang, media, maupun strategi cara belajar peserta didik dengan variasi berbeda dalam pembelajaran. Orang dapat mengingat 20\% melalui penglihatan, 30\% melalui pendengaran, dan $50 \%$ melalui penglihatan dan pendengaran serta $80 \%$ melalui penglihatan, pendengaran, aktivitas yang dilakukan pada saat yang bersamaan (Munir dalam Putra, 2019). Sehingga guru dapat memanfaatkan media untuk menyampaikan materi pembelajaran. Media pembelajaran bisa menjadikan kegiatan pembelajaran menjadi lebih menarik, meningkatkan keaktifan dan motivasi peserta didik, serta dapat membuat peserta didik lebih mudah dalam mencerna materi (Rahmat, 2015). Media pembelajaran saat ini membutuhkan inovasi agar sesuai dengan perkembangan zaman.

Menurut hasil wawancara dengan guru pada saat melaksanakan studi pendahuluan, informasi yang bisa diperoleh yaitu media pembelajaran yang dipergunakan oleh guru pada mata pelajaran praktikum akuntansi perusahaan manufaktur yaitu powerpoint. Selain itu, dalam proses pembelajaran guru masih memakai metode ceramah. Metode ini condong membuat peserta didik menjadi kurang aktif dan dapat menurunkan konsentrasi bila peserta didik hanya bisa mendengarkan saja, kecuali bila mereka tertarik dengan materi yang disampaikan oleh guru (Machmuda dan Rosyidi dalam Kanah, 2016).

Peserta didik merasa bila materi laporan harga pokok perusahaan manufaktur tergolong ke dalam materi yang sukar. Hal ini dikarenakan kompetensi dasar pada materi ini berbeda dari sebelumnya. Sehingga materi ini termasuk ke dalam materi yang baru pada mata pelajaran praktikum akuntansi perusahaan manufaktur. Ketika menjelaskan materi penggolongan biaya overhead pabrik, guru hanya menyampaikan secara verbal saja. Sehingga peserta didik hanya dapat membayangkan saja, tanpa ada ilustrasi mengenai materi ini.

Dari permasalahan tersebut, peserta didik memerlukan media pembelajaran yang bisa menumbuhkan hasrat dan motivasi peserta didik dalam belajar, serta bisa membuat peserta didik menjadi lebih menguasai materi pelajaran. Media pembelajaran ialah sebuah sarana untuk membantu mengajar yang terdapat pada unsur metodologi yang dipakai pada lingkungan belajar dan disusun oleh guru (Sudjana \& Achmad, 2017:1). Media pembelajaran yang hendak dikembangkan peneliti ialah media pembelajaran berbantuan komputer atau multimedia interaktif. Media pembelajaran ini memakai teknologi yang dikemas secara menarik sehingga bisa membangkitkan keinginan peserta didik agar bisa belajar dengan giat. Salah satu media yang dapat membangkitkan keinginan peserta didik di era teknologi sekarang ini yaitu media pembelajaran interaktif.

Multimedia interaktif yakni penggabungan dari media berupa audio, teks, grafik, gambar, dan video yang bisa dimanipulasi oleh pemakainya sehingga dapat menjalankan arahan dari presentasi (Prastowo, 2015:329). Berdasarkan pada fasilitas yang ada di sekolah, guru dapat membuat media 
pembelajaran interaktif berbasis komputer. Guru harus menemukan media yang tepat yang bisa diakses oleh siswa dengan menggunakan semua perangkat. Salah satu media pembelajaran interaktif yang bisa dipakai oleh guru yaitu lectora inspire.

Lectora Inspire merupakan perangkat lunak yang bisa dipergunakan untuk menyatukan flash, merekam video, memadukan gambar, serta menangkap layar (Mas'ud, 2014:1). Alasan terpenting pemilihan media pembelajaran berbasis lectora inspire ini aialah adanya pengaruh kemajuan teknologi dan informasi dalam ranah pendidikan. Peserta didik didorong memiliki pemikiran yang terbuka agar tidak tertinggal oleh zaman. Media pembelajaran ini dapat mudah diakses oleh siswa karena dapat dijalankan secara offline. Selain itu, penggunaan aplikasi lectora inspire memiliki manfaat, diantaranya mudah untuk mengembangkan media, memiliki fitur untuk menyatukan materi dan evaluasi berupa kuis atau game sehingga memudahkan guru dalam mengoperasikannya, dapat menampilkan slide materi yang di dalamnya berisi teks, video, suara, dan animasi, serta memiliki konten yang lengkap yang dapat memudahkan guru untuk mengembangkan kreativitasnya sehingga dapat membuat media pembelajaran yang menarik. Lectora Inspire dapat menjadi solusi dalam membuat media pembelajaran interaktif yang dipergunakan pada ranah pendidikan dengan kelebihan kecepatan kapasitas bawaan pengembangan (Ionita, L. \& Ionita, 2011:1-2).

Media pembelajaran ini dilengkapi dengan berbagai fitur yang interaktif, video pengamatan, materi, dan latihan soal. Media pembelajaran ini sudah disesuaikan dengan aktivitas pembelajaran pada kurikulum 2013. Yang mana dalam kurikulum 2013, semua aktivitas pembelajarannya menggunakan pendekatan saintifik (saintific approach). Keunggulan yang lain yaitu dalam latihan soal terdapat umpan balik sehingga siswa dapat mengetahui skor hasil pengerjaanya, serta disajikan pembahasan pada setiap latihan soal. Dengan adanya latihan soal yang disertai pembahasan, peserta didik bisa lebih mengerti materi dan dapat termotivasi dalam belajar sehingga peserta didik bisa menggapai tujuan yang diimpikan.

Berlandasakan dari penjabaran di atas, peneliti terdorong untuk melaksanakan penelitian pengembangan dengan judul
"Pengembangan Media Pembelajaran Interaktif Berbasis Lectora Inspire Pada Materi Laporan Harga Pokok". Rumusan masalah dalam penelitian ini adalah: 1) Bagaimana proses mengembangkan media pembelajaran interaktif berbasis lectora inspire pada materi laporan harga?; 2) Bagaimana kelayakan media pembelajaran interaktif berbasis lectora inspire pada materi laporan harga pokok?; 3) Bagaimana respon peserta didik terhadap media pembelajaran interaktif berbasis lectora inspire pada materi laporan harga pokok?. Bersumber dari rumusan masalah tersebut, maka tujuan dalam penelitian ini adalah: 1) Menghasilkan produk berupa media pembelajaran interaktif berbasis lectora inspire pada materi laporan harga pokok; 2) Menganalisis kelayakan media pembelajaran interaktif berbasis lectora inspire pada materi laporan harga pokok; 3) Menganalisis respon peserta didik terhadap media pembelajaran interaktif berbasis lectora inspire pada materi laporan harga pokok.

\section{METODE}

Penelitian ini tergolong dalam Research and Development yaitu metode penelitian yang memiliki tujuan untuk menciptakan dan melakukan pengujian atas produk yang dikembangkan (Sugiyono, 2015:2). Model ADDIE yang dimodifikasi oleh Branch merupakan model pengembangan yang dipilih oleh peneliti. Model pengembangan ADDIE memiliki konsentrasi pada tujuan pembelajaran, terlebih pada media pembelajaran. Model ADDIE mencakup lima fase, diantaranya fase Analysis (Analisis), Design (Desain), Development (Pengembangan), Implementation (Implementasi), dan Evaluation (Evaluasi). Berikut merupakan fase model pengembangan ADDIE.

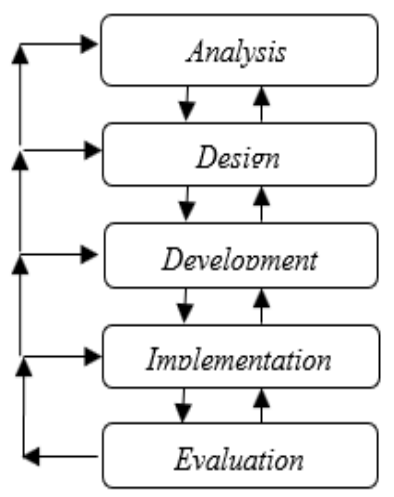

Gambar 1. Fase model pengembangan ADDIE Sumber: Suryani, dkk (2018) 
Pada penelitian pengembangan ini, peneliti hanya melaksanakan tahapan pengembangan ADDIE sampai dengan tahap implementasi saja dikarenakan adanya keterbatasan peneliti. Model pengembangan ini bersifat luwes dan umum. Selain itu, model ini mudah untuk dipelajari dan tahapannya saling berhubungan satu sama lain. Sehinga untuk menciptakan produk yang efektif dan efisien, setiap langkah yang akan dilalui harus dilakukan secara bertahap dan menyeluruh.

Media pembelajaran ini diujicobakan pada dua ahli materi yakni satu dosen Pendidikan Akuntansi dan satu guru praktikum akuntansi perusahaan manufaktur di SMK Negeri 2 Tuban, satu ahli media yaitu dosen Kurikulum dan Teknologi Pendidikan, serta 20 peserta didik dari kelas XII Akuntansi di SMK Negeri 2 Tuban yang dipilih secara acak. Data yang dipakai dalam penelitian ini adalah data kualitatif dan data kuantitatif. Data kualitatif adalah data yang berisi kata atau kalimat. Sementara itu, data kualitatif yaitu data yang berisi angka (Sugiyono, 2015:23)

Instrumen yang dipakai dalam menghimpun data ialah angket. Angket ini dipergunakan untuk mengetahui hasil penilaian atas produk yang dikembangkan. Pada penelitian ini, angket yang dipergunakan adalah angket terbuka dan angket tertutup. Angket terbuka berupa lembar telaah ahli materi dan lembar telaah ahli media. Angket tertutup berupa lembar validasi ahli materi dan ahli media, serta angket respon peserta didik.

Teknis analisis data yang digunakan dalam penelitian ini meliputi 1) Lembar telaah para ahli; 2) Lembar validasi para ahli. Persentase tersebut bisa diperoleh dari perhitungan skor yang terdapat pada lembar validasi para ahli dengan menggunakan skala Likert. 3) Angket respon peserta didik dianalisis dengan teknik deskriptif kuantitatif dalam bentuk persentase. Media yang dikembangkan oleh peneliti dapat dikatakan layak bila memperoleh persentase $\geq 61 \%$.

Tabel 1. Skala Likert

\begin{tabular}{lc}
\hline \multicolumn{1}{c}{ Kriteria } & Nilai/Skor \\
\hline Sangat baik & 5 \\
\hline Baik & 4 \\
\hline Sedang & 3 \\
\hline Sangat Buruk & 2 \\
\hline Buruk Sekali & 1 \\
\hline \multicolumn{2}{c}{ Sumber : Riduwan (2016:17) }
\end{tabular}

Tabel 2. Skala Guttman

\begin{tabular}{|c|l|}
\hline Jawaban & Skor \\
\hline Ya & 1 \\
\hline Tidak & 0 \\
\hline
\end{tabular}

Sumber : Riduwan ( 2016:17)

Kemudian dihitung dengan rumus:

$$
\text { Persentase }=\frac{(\text { Jumlah Skor })}{(\text { Skor Maksimal })} \times 100 \%
$$

Tabel 3. Kriteria Interpretasi

\begin{tabular}{cc}
\hline Penilaian & Kriteria Interpretasi \\
\hline $0 \%-20 \%$ & Sangat tidak layak \\
\hline $21 \%-40 \%$ & Tidak layak \\
\hline $41 \%-60 \%$ & Cukup layak \\
\hline $61 \%-80 \%$ & Layak \\
\hline $81 \%-100 \%$ & Sangat Layak \\
\hline
\end{tabular}

Sumber : Riduwan ( 2016:15)

\section{HASIL DAN PEMBAHASAN \\ Proses Pengembangan}

Secara garis besar, pengembangan media pembelajaran berbasis lectora inspire dilaksanakan dengan memakai model ADDIE. Model ini memiliki lima fase, diantaranya fase analysis, design, development, implementation, dan evaluation. Pada penelitian pengembangan ini, peneliti hanya melaksanakan tahapan pengembangan ADDIE sampai dengan tahap implementasi saja dikarenakan adanya keterbatasan peneliti.

Fase pertama yaitu analysis, peneliti melakukan analisis melalui tiga langkah. Langkah pertama yaitu analisis kinerja. Analisis kinerja dilaksanakan dengan maksud untuk memperoleh informasi yang berpautan dengan persoalan kinerja yang dijumpai oleh guru, peserta didik, dan sekolah dalam kegiatan pembelajaran. Berdasarkan pada analisis kinerja yang sudah dilaksanakan oleh peneliti, diperoleh informasi bila SMK Negeri 2 Tuban telah menerapkan kurikulum 2013, tetapi guru masih menerapkan metode ceramah ketika pembelajaran. Pada saat melaksanakan aktivitas pembelajaran, guru memakai media powerpoint dan bahan ajar berupa buku cetak. Peserta didik memiliki kesukaran dalam memahami materi laporan harga pokok perusahaan manufaktur, khususnya pada materi penggolongan biaya overhead pabrik karena ilustrasi yang ada di buku dan penjelasan guru belum dapat menggambarkan secara nyata. Peserta didik kelas XII Akuntansi di SMK Negeri 2 Tuban 
memiliki kemampuan yang heterogen. Peserta didik berada pada usia beranjak dewasa sehingga mereka sudah mampu untuk menalar yaitu mampu menghubungkan antara fakta dengan logika. Langkah kedua yakni analisis kebutuhan yang digunakan untuk mengetahui kebutuhan guru, peserta didik, ataupun sekolah yang digunakan untuk menjawab persoalanpersoalan pada analisis kinerja. Dari kegiatan menganalisis kebutuhan, diperoleh suatu hasil yaitu dibutuhkannya media pembelajaran yang bisa merangsang peserta didik untuk aktif dalam proses pembelajaran serta mampu memahami memahami dan menggambarkan contoh dari masing-masing komponen penggolongan biaya overhead pabrik secara nyata. Langkah yang terakhir yaitu analisis tujuan pembelajaran. Analisis ini digunakan dalam penyusunan materi pelajaran dan menentukan pokok dalam media pembelajaran sehingga dapat dijadikan pijakan dalam memproduksi media pembelajaran interaktif.

Fase kedua adalah design atau perancangan produk. Untuk merancang suatu produk, sebelumnya peneliti harus mengidentifikasi kompetensi yang dimiliki oleh peserta didik sehingga tujuan pembelajaran yang dibuat bisa tercapai. Penelitian ini akan menghasilkan produk berupa media pembelajaran interaktif berbasis lectora inspire. Pada fase ini peneliti membuat storyboard atau rancangan produk. Storyboard merupakan dari media pembelajaran yang dibuat. Di dalam storyboard terdapat desain rancangan produk yang dimulai dari tampilan awal, menu utama, petunjuk penggunaan, kompetensi dasar, materi, quiz, hingga profil pengembang. Selain itu, peneliti juga merancang materi yang akan dimasukkan ke dalam media pembelajaran sesuai dengan kompetensi dasar.

Fase ketiga yaitu fase development. Peneliti mengaplikasikan rancangan produk dari storyboard yang sudah dibuat pada fase sebelumnya dengan cara membuat media pembelajaran interaktif. Peneliti melaksanakan beberapa prosedur yang dipakai untuk mengembangkan media ini diantaranya, menyusun produk media pembelajaran interaktif, telaah para ahli, kemudian melakukan validasi para ahli. Langkah pertama, menyusun media pembelajaran interaktif. Peneliti merancang produk media pembelajaran dengan memakai aplikasi lectora inspire V18.1.2. Produk yang dihasilkan nantinya berformat (.exe) dan html sehingga bisa dioperasikan di seluruh perangkat. Materi pelajaran yang akan dimasukkan harus disesuaikan dengan materi laporan harga pokok perusahaan manufaktur yang memuat tiga kompetensi dasar yakni KD 3.29 sampai dengan KD 3.31 yang didalamnya berisi materi biaya overhead pabrik, metode harga pokok pesanan, dan metode harga pokok proses produksi. Tata letaknya harus sinkron dengan storyboard yang telah dibuat.

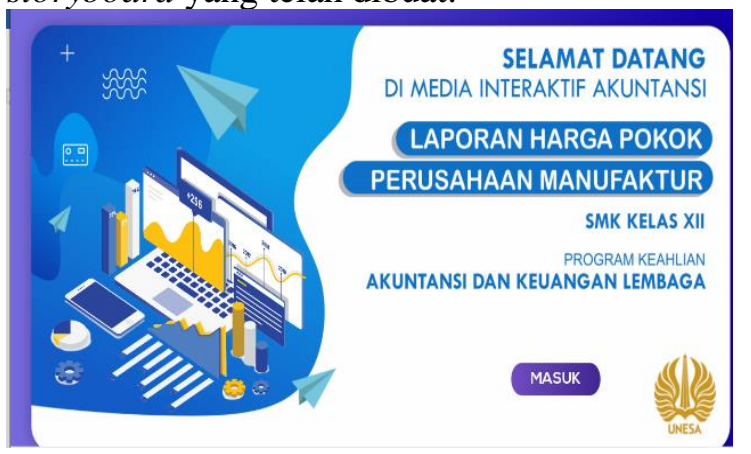

Gambar 2. Tampilan halaman depan media pembelajaran interaktif

Langkah berikutnya yaitu telaah para ahli. Media pembelajaran ini kemudian akan ditelaah oleh para ahli yang terdiri dari dua ahli materi dan satu ahli media dengan cara melakukan pengisian pada lembar telaah yang dibuat. Hal ini bertujuan untuk memperoleh saran ataupun masukan dari para ahli demi kesempurnaan produk. Setelah itu, peneliti akan membenahi produk berdasarkan saran atau masukan para ahli. Saran dari ahli materi adalah menyesuaikan gambar dengan kegiatan perusahaan. Sedangkan saran dari ahli media adalah menambahkan bahan penyerta berupa petunjuk penggunaan media bagi guru dan peserta didik dan produk akhir dikemas dalam flashdisk.

Langkah terakhir yaitu melakukan validasi para ahli. Validasi ini berisi penilaian atas media yang dikembangkan oleh ahli materi dan ahli media terhadap produk yang dibuat sebelum dilaksanakan uji coba kepada peserta didik. Setelah memperoleh penilaian dari validator, peneliti dapat mengolah hasilnya dengan menggunakan teknik deskriptif kuantitatif dalam bentuk persentase. Sehingga produk media pembelajaran interaktif siap untuk diujicobakan. 


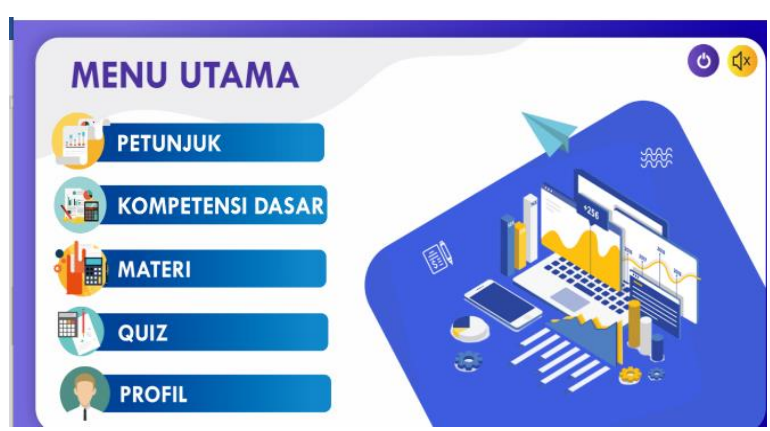

Gambar 3. Tampilan menu utama media pembelajaran interaktif

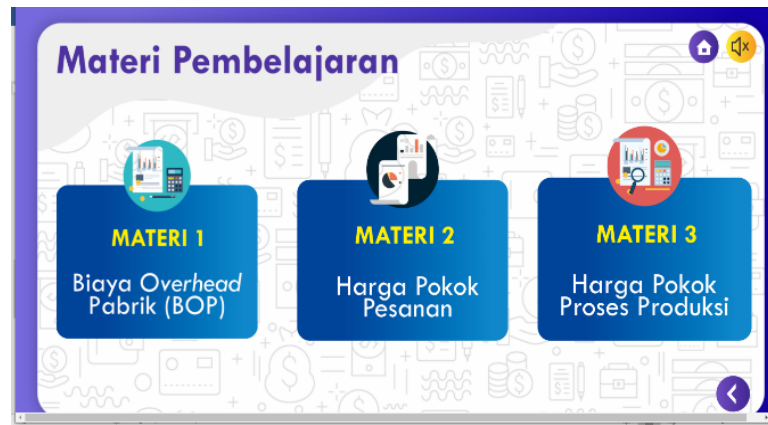

Gambar 4. Tampilan menu materi pembelajaran

Fase keempat yaitu implementation. Fase ini memiliki tujuan untuk mengetahui respon peserta didik terhadap media yang dikembangkan. Uji coba dilaksanakan secara terbatas pada 20 peserta didik kelas XII Akuntansi dan Keuangan Lembaga di SMK Negeri 2 Tuban yang mempunyai kemampuan heterogen yang dipilih oleh guru. Media pembelajaran ini berbentuk aplikasi yang dapat diinstal di komputer/laptop yang diunggah di Google Drive. Kemudian peserta didik dapat mengunduh dan menginstal di komputer/laptop. Peserta didik terlebih dahulu diberikan penjelasan mengenai media pembelajaran ini, lalu peserta didik diminta untuk mengoperasikan media pembelajaran dengan menggunakan komputer/laptop. Setelah itu, peserta didik diarahkan untuk mengisi angket respon siswa yang telah disiapkan oleh peneliti. Data hasil respon peserta didik kemudian akan dianalisis berdasarkan pada penilaian peserta didik terhadap media pembelajaran yang telah diujicobakan. Hasil dari angket respon peserta didik akan dianalisis melalui perhitungan skor berdasarkan pada Skala Guttman yang kemudian dianalisis dengan teknik deskriptif kuantitatif dalam bentuk persentase.

\section{Kelayakan Pengembangan}

Kelayakan media pembelajaran interaktif diukur berdasarkan hasil validasi para ahli. Ahli materi media pembelajaran interaktif ini adalah Drs. Joni Susilowibowo, M.Pd. dan Dra. Retno Sulistyowati. Sedangkan yang menjadi ahli media yaitu Dr. Andi Kristanto, S.Pd., M.Pd. Data hasil dari validasi lalu diolah melalui teknik persentase dan ditafsirkan hasilnya. Berikut merupakan rekapitulasi hasil validasi ahli materi.

Tabel 4. Rekapitulasi Hasil Validasi Ahli Materi No Variabel Total Presen- Kriteria Skor tase

\begin{tabular}{|clcccc} 
& & \multicolumn{2}{c}{ Skor } & tase & \\
\cline { 3 - 4 } $\mathbf{1}$ & $\begin{array}{l}\text { K1 } \\
\text { Kualitas isi } \\
\text { dan tujuan }\end{array}$ & 22 & 22 & $88 \%$ & $\begin{array}{l}\text { Sangat } \\
\text { layak }\end{array}$ \\
\hline $\mathbf{2}$ & $\begin{array}{l}\text { Kualitas } \\
\text { instruksional }\end{array}$ & 28 & 27 & $91,65 \%$ & $\begin{array}{l}\text { Sangat } \\
\text { layak }\end{array}$ \\
\hline $\mathbf{3}$ & $\begin{array}{l}\text { Kualitas } \\
\text { teknis }\end{array}$ & 42 & 37 & $87,75 \%$ & $\begin{array}{l}\text { Sangat } \\
\text { layak }\end{array}$ \\
\hline Rata-rata Variabel & & $\mathbf{8 9 , 1 3 \%}$ & $\begin{array}{l}\text { Sangat } \\
\text { layak }\end{array}$ \\
\hline & Sumber: Data diolah peneliti (2020)
\end{tabular}

Menurut tabel di atas, diperoleh data skor dari media pembelajaran interaktif berbasis lectora inspire yang memuat variabel kualitas isi dan tujuan, kualitas instruksional, dan kualitas teknis memperoleh rata-rata persentase sejumlah $89,13 \%$, sehingga dapat dikategorikan "sangat layak".

Tabel 5. Rekapitulasi Hasil Validasi Ahli Media

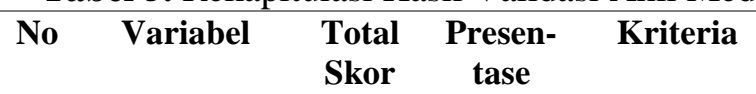

\begin{tabular}{clccc}
\hline $\mathbf{1}$ & $\begin{array}{l}\text { Kualitas isi } \\
\text { dan tujuan }\end{array}$ & 22 & $88 \%$ & $\begin{array}{c}\text { Sangat } \\
\text { layak }\end{array}$ \\
\hline $\mathbf{2}$ & $\begin{array}{l}\text { Kualitas } \\
\text { instruksional }\end{array}$ & 26 & $86,67 \%$ & $\begin{array}{l}\text { Sangat } \\
\text { layak }\end{array}$ \\
\hline $\mathbf{3}$ & $\begin{array}{l}\text { Kualitas } \\
\text { teknis }\end{array}$ & 36 & $80 \%$ & Layak \\
\hline Rata-rata Variabel & & $\mathbf{8 4 , 8 9 \%}$ & $\begin{array}{l}\text { Sangat } \\
\text { Layak }\end{array}$ \\
\hline
\end{tabular}

Sumber: Data diolah peneliti (2020)

Jika dilihat pada tabel 2, dapat diketahui bila skor dari media pembelajaran interaktif yang dihitung dari seluruh variabel mendapatkan rata-rata persentase sejumlah $84,89 \%$, dengan kategori "sangat layak".

\section{Respon Peserta Didik}

Respon peserta didik didapat dari hasil uji coba terbatas pada 20 peserta didik kelas XII Akuntansi dan Keuangan Lembaga SMK 
Negeri 2 Tuban. Berikut ini adalah rekapitulasi hasil respon peserta didik.

Tabel 6. Rekapitulasi Hasil Respon Peserta Didik

\begin{tabular}{|c|l|c|c|}
\hline No & \multicolumn{1}{|c|}{ Variabel } & $\begin{array}{c}\text { Presen- } \\
\text { tase }\end{array}$ & $\begin{array}{c}\text { Kri- } \\
\text { teria }\end{array}$ \\
\hline 1 & $\begin{array}{l}\text { Kualitas isi dan } \\
\text { tujuan }\end{array}$ & $96,67 \%$ & $\begin{array}{c}\text { Sangat } \\
\text { Memahami }\end{array}$ \\
\hline 2 & $\begin{array}{l}\text { Kualitas } \\
\text { instruksional }\end{array}$ & $92,23 \%$ & $\begin{array}{c}\text { Sangat } \\
\text { Memahami }\end{array}$ \\
\hline 3 & Kualitas teknis & $93,75 \%$ & $\begin{array}{c}\text { Sangat } \\
\text { Memahami }\end{array}$ \\
\hline \multicolumn{2}{|c|}{ Rata-rata variabel } & $\mathbf{9 4 , 2 2 \%}$ & $\begin{array}{c}\text { Sangat } \\
\text { Memahami }\end{array}$ \\
\hline
\end{tabular}

Sumber: Data diolah peneliti (2020)

Menurut tabel di atas, didapat informasi bila hasil respon peserta didik pada variabel isi dan tujuan mendapat rata-rata persentase sejumlah 96,67\%. Skor ini menyatakan bahwa peserta didik sudah tergolong pada kriteria "sangat memahami". Berdasarkan pada presentase tersebut, media pembelajaran interaktif sudah memuat aspek ketepatan, minat, dan kesesuaian.

Pada variabel kualitas instruksional, media ini mendapatkan kriteria sangat memahami. Hal ini bisa dibuktikan bahwa media pembelajaran interaktif dapat memberi keleluasaan belajar dan mampu memotivasi peserta didik dalam belajar.

Pada variabel kualitas teknis, persentase yang diperoleh adalah sebesar $93,75 \%$, skor ini tergolong ke dalam kriteria "sangat memahami". Sehingga dapat dinyatakan bila media pembelajaran interaktif sudah memuat aspek keterbacaan, mudah untuk dibaca, memiliki tampilan yang menarik, serta mudah dalam mengelola program.

Sehingga dapat ditarik kesimpulan hasil respon peserta didik terhadap media pembelajaran interaktif berbasis lectora inspire mendapat persentase rata-rata sejumlah $94,22 \%$ dan termasuk ke dalam kriteria "sangat memahami".

Penelitian serupa juga dilakukan oleh Rindang Andiarsa (2017) dengan rata-rata nilai keseluruhan sebesar 88,79\% dengan kriteria "sangat layak". Sehingga dapat disimpulkan bahwa media ini sangat layak digunakan pada mata pelajaran praktikum akuntansi perusahaan manufaktur materi laporan harga pokok perusahaan manufaktur kelas XII Akuntansi dan Keuangan Lembaga di SMK Negeri 2 Tuban.

\section{PENUTUP \\ Simpulan}

Simpulan pada penelitian ini, diantaranya: (1) Pengembangan media pembelajaran interaktif berbasis lectora inspire memakai model pengembangan ADDIE yang meliputi lima fase yaitu analisis, desain, pengembangan, implementasi, dan evaluasi. (2) Media pembelajaran interaktif berbasis lectora inspire dinyatakan "sangat layak" menurut penilaian hasil validasi dari para ahli, sehingga dapat dipergunakan dalam pembelajaran. (3) Peserta didik memberikan reaksi positif terhadap media pembelajaran interaktif berbasis lectora inspire dengan kriteria "sangat memahami".

\section{Saran}

Saran yang diberikan oleh peneliti, diantaranya: (1) Diharapkan peneliti lain bisa mengembangkan media pembelajaran interaktif dengan menggunakan materi praktikum akuntansi perusahaan manufaktur yang berbeda dengan tampilan dan varian yang kian menarik. (2) Disarankan agar peneliti lain dapat melaksanakan penelitian pengembangan ADDIE secara lengkap sampai dengan tahap evaluasi. (3) Diharapkan peneliti lain mampu mengembangkan media pembelajaran interaktif yang dapat diakses dengan semua perangkat baik laptop, komputer, macbook, ataupun android sehingga dapat memudahkan pengguna dalam mengoperasikannya. (4) Diharapkan untuk peneliti lain agar dapat melakukan penelitian eksperimen untuk mengetahui efektivitas penggunaan media pembelajaran ini.

\section{DAFTAR PUSTAKA}

Abidin. 2014. Desain Sistem Pembelajaran dalam Konteks Kurikulum 2013. Refika Aditama.

Fatkhurrohman, A., \& Susilowibowo, J. 2019. Pengembangan Media Pembelajaran Berbasis Video Menggunakan Cartoon Character Pada Materi Transaksi Perusahaan Manufaktur Kelas X AKL SMK Negeri 2 Buduran. Jurnal Pendidikan Akuntansi (JPAK), 7(2), 122128.

Ionita, L. \& Ionita, I. 2011. Lectora-a Complete e-Learning Solution. Makalah disajikan dalam The 6th International Conference on Virtual Learning ICVL.

Kanah, S. 2016. Pengembangan Media Pembelajaran Audio Visual (Video) Pada 
Materi Pengisian SPT Tahunan PPH Wajib Pajak Orang Pribadi Kelas XII Akuntansi Di SMK Negeri 10 Surabaya. Jurnal Pendidikan Akuntansi (JPAK), 1, $1-8$.

Mas'ud, M. 2014. Membuat Multimedia Pembelajaran dengan Lectora. Yogyakarta: Pustaka Shonif.

Prastowo. 2015. Panduan Kreatif Membuat Bahan Ajar Inovatif. Diva Press.

Putra, A. P., Soepriyanto, Y., \& Husna, A. 2019. Pengembangan Multimedia Game Edukasi Tentang Keragaman Masakan Khas Daerah-daerah di Indonesia Untuk Kelas V SD. Jurnal Kajian Teknologi. 299-306.

Rahmat, S. T. 2015. Pemanfaatan Multimedia Interaktif Berbasis Komputer Dalam Pembelajaran. Jurnal Pendiikan Dan Kebudayaan Missio, 7(2), 196-208.

Riduwan. 2016. Skala Pengukuran dan Variabel-Variabel Penelitian. Alfabeta.

Sudjana, N., \& Achmad, R. 2017. Media Pengajaran. Sinar Baru Algensindo.

Sugiyono. 2015. Metode Penelitian \& Pengembangan: Research and Development. Alfabeta.

Suryani, N., Setiawan, A., \& Putria, A. 2018. Media Pembelajaran Inovatif dan Pengembangannya: Remaja Rosdakarya.

Wahyuni, Y. 2017. Identifikasi Gaya Belajar (Visual, Auditorial, Kinestetik) Mahasiswa Pendidikan Matematika Universitas Bung Hatta. Jurnal Penelitian Dan Pembelajaran Matematika, 10(2), 128-132. 